\title{
Tourists, Tourism and the Good Life
}

Philip Pearce,

Sebastian Filep and Glenn Ross 


\section{Tourists, Tourism and the Good Life}

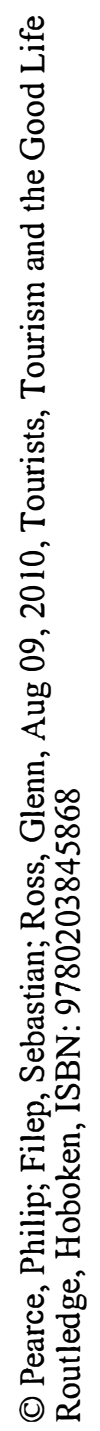




\title{
Routledge Advances in Tourism
}

\author{
Edited by Stephen Page, University of Stirling, Scotland
}

1. The Sociology of Tourism

Theoretical and Empirical Investigations

Edited by Yiorgos Apostolopoulos,

Stella Leivadi and Andrew Yiannakis

\section{Creating Island Resorts \\ Brian King}

3. Destinations

Cultural Landscapes of Tourism

Greg Ringer

\section{Mediterranean Tourism}

Facets of Socioeconomic

Development and Cultural Change

Edited by Yiorgos Apostolopoulos, Lila

Leontidou and Philippos Loukissas

5. Outdoor Recreation Management John Pigram and John Jenkins

\section{Tourism Development}

Contemporary Issues

Edited by Douglas G. Pearce and

Richard W. Butler

\section{Tourism and Sustainable}

Community Development

Edited by Greg Richards and

Derek Hall

\section{Tourism and Political Boundaries \\ Dallen J. Timothy}

9. Leisure and Tourism Landscapes Social and Cultural Geographies Cara Aitchison, Nicola E. MacLeod and Stephen J. Shaw
10. Tourism in the Age of

Globalisation

Edited by Salah Wahab and

Chris Cooper

11. Tourism and Gastronomy

Edited by Anne-Mette Hjalager and

Greg Richards

12. New Perspectives in

Caribbean Tourism

Edited by Marcella Daye, Donna

Chambers and Sherma Roberts

13. The Advanced Econometrics

of Tourism Demand

Haiyan Song, Stephen F. Witt

and Gang Li

\section{Tourism in China}

Destination, Cultures and Communities

Edited by Chris Ryan and Gu Huimin

\section{Sustainable Tourism Futures}

Perspectives on Systems,

Restructuring and Innovations

Edited by Stefan Gössling, C. Michael

Hall and David B. Weaver

16. Handbook of Tourist Behavior

Theory and Practice

Edited by Metin Kozak and Alain

Decrop

17. Advances in Tourism Research

Edited by Metin Kozak, Luisa Andreu and Juergen Gnoth 
18. Tourism Enterprises and

Sustainable Development

International Perspectives on

Responses to the Sustainability

Agenda

Edited by David Leslie

19. Tourist Mobility and Advanced

Tracking Technologies

Noam Shoval and Michal Isaacson

20. Tourists, Tourism and the

Good Life

Philip Pearce, Sebastian Filep and

Glenn Ross 


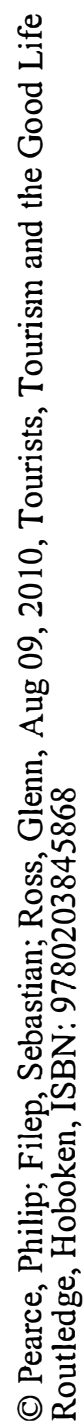




\section{Tourists, Tourism and the Good Life}

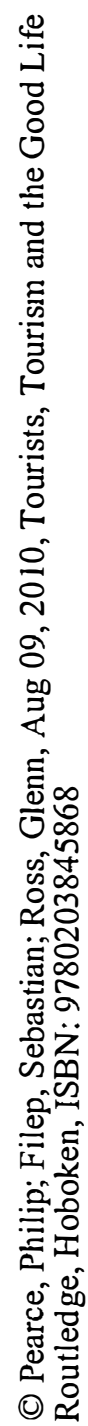

\section{Philip Pearce, Sebastian Filep and Glenn Ross}

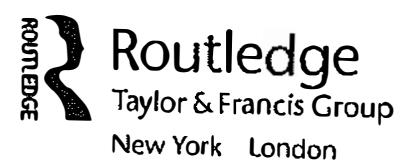


First published 2011

by Routledge

270 Madison Avenue, New York, NY 10016

Simultaneously published in the UK

by Routledge

2 Park Square, Milton Park, Abingdon, Oxon OX14 4RN

Routledge is an imprint of the Taylor \&r Francis Group, an informa business

This edition published in the Taylor \& Francis e-Library, 2010.

To purchase your own copy of this or any of Taylor \& Francis or Routledge's

collection of thousands of eBooks please go to www.eBookstore.tandf.co.uk.

(C) 2011 Taylor \& Francis

The right of Philip Pearce, Sebastian Filep and Glenn Ross to be identified as authors of this work has been asserted by them in accordance with sections 77 and 78 of the Copyright, Designs and Patents Act 1988.

All rights reserved. No part of this book may be reprinted or reproduced or utilised in any form or by any electronic, mechanical, or other means, now known or hereafter invented, including photocopying and recording, or in any information storage or retrieval system, without permission in writing from the publishers.

Trademark Notice: Product or corporate names may be trademarks or registered trademarks, and are used only for identification and explanation without intent to infringe.

\section{Library of Congress Cataloging-in-Publication Data}

Pearce, Philip L.

Tourists, tourism and the good life / by Philip Pearce, Sebastian Filep and Glenn Ross.

p. cm. - (Routledge advances in tourism; v.20)

Includes bibliographical references and index.

1. Tourism-Psychological aspects. I. Filep, Sebastian. II. Ross, Glenn F.

III. Title.

G155.A1P3624 2010

306.4' $819-\mathrm{dc} 22$

2010006198

ISBN 0-203-84586-2 Master e-book ISBN

ISBN13: 978-0-415-99329-6 (hbk)

ISBN13: 978-0-203-84586-8 (ebk) 


\section{Contents}

List of Figures ix

List of Tables xi

I Preface and Acknowledgments xiii

Introduction $\quad \mathrm{xv}$

1 Scholarship in Psychology and Tourism 1

PART I

Principally About Individuals 27

2 Flow and Tourist Satisfaction 31

3 Time, Tourism, Host Communities and Positive Psychology 63

4 Ethics, Tourism and Well-being 81

PART II

Individuals and Tourism Contexts 103

5 Materialism in Tourism and Its Alleviation Through Good Values

6 Lifestyle Businesses and Their Community Effects 122

7 Spa and Wellness Tourism and Positive Psychology 142

8 Summary, Synthesis and Future Directions 164

Bibliography 183

Author Biographies 213

Author Index 215

Subject Index 223 


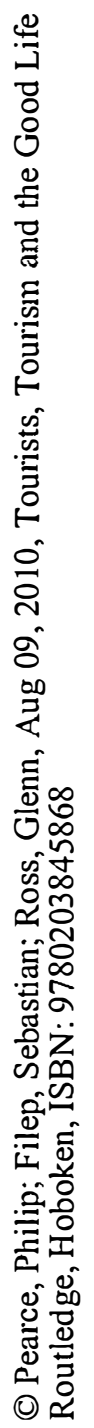




\section{Figures}

2.1 Core contextual and immediate conscious satisfaction themes.

4.1 Predictive pathways among the dimensions wisdom, ethics, tourism issues and personal well-being within tourism settings.

5.1 Transcending materialism in tourism through education values.

6.1 Perceived value positions for lifestyle entrepreneurs.

7.1 The core structure of the travel career patterns (TCP) approach. 


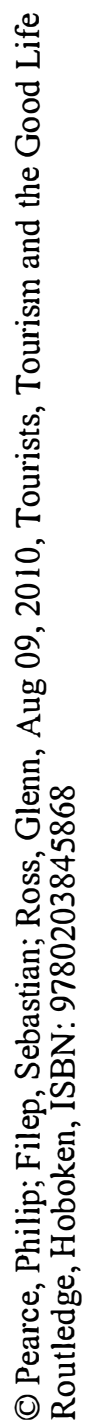




\section{Tables}

2.1 Coder 1 Set-Immediate On-Site Satisfaction Themes 50

5.1 Key Costs of Materialism in Tourism

5.2 Beyond Materialism in Tourism Education: Suggested Lecture Topics

6.1 The Positive Psychology View of Character Strengths Which Build Well-Being and Happiness

7.1 A Sample of Needs Identified in Psychology Writing and Research

7.2 Requirements for a Conceptual Scheme to Understand Tourist Motivation

8.1 Positive Psychology and Tourism: Synthesis of the Core Contributions

8.2 Proposed Values for Tourism Education

8.3 Positive Psychology Contributions in the Tourist Experience Phases 


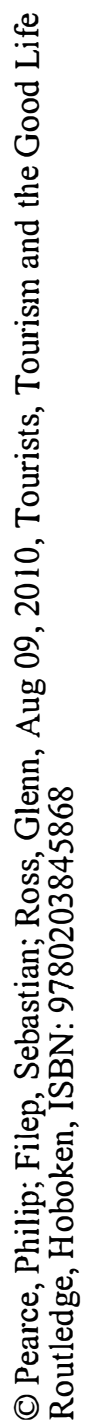




\section{Preface and Acknowledgments}

Most of us at least at some stage of our lives ponder over the following questions: Am I leading a good life at the moment? How could I make my life better in the future? Or later in our lives we ask ourselves: Have I led a good life and how did I define it? The special interest in this book is on the role of the tourism context in promoting the positive experiences that lead to a good life: positive emotions, engagement and meaning. Like our pondering over the good life, tourist trips can be conceived in terms of time: we anticipate positive emotions at destinations, we value being immediately satisfied and engaged at the places we visit, and we reflect back on our holidays and sometimes gain wisdom and meaning from them.

The chapters in this volume plot a pathway to understanding this very important human desire to lead a good life in the context of being a tourist and in other contexts relevant to the world of tourism. The book represents the efforts of three academics, two of whom have detailed research backgrounds in psychology and tourism, one of whom has recently completed his doctorate work on the topic. The two core aims of the book are to: 1) offer a resource of new methodological and conceptual tools for scholars and students; and 2) to orient the audience to a fresh awareness of the value of well-being ideas from positive psychology and the research field's role in understanding the good life.

A somewhat unusual feature of this book is the integrating part introductions which present lead-in comments. These are contextual statements raising issues in the whole area defined by the part titles: "Principally About Individuals" (Part I) and "Individuals and Tourism Contexts" (Part II). Chapter 1 is also preceded by its own introduction. The introductions place all the specific chapters in a context. It is recognised that a book of this sort needed this "glue" to make it a coherent and complete statement while further recognising that all topics could not be covered. The three authors worked closely and tried to achieve stylistic consistency as much as possible while completing the chapter contributions.

Professional assistance of several people is highly appreciated. From James Cook University, we would like to thank Mrs. Robyn Yesberg for her cheerfulness and administrative assistance. From Victoria University, 
xiv Preface and Acknowledgments

we would like to thank Professor Margaret Deery for her encouragement of this book initiative and the Centre for Tourism and Services Research staff for their advice and administrative support.

We hope you'll enjoy our small contribution to the good life!

Philip Pearce, Sebastian Filep and Glenn Ross Australia, 2010 


\section{Introduction}

It is appropriate at the start of this book to introduce Generation T. Who belongs to this newly designated group? In answering the question, readers do not have to recall their birth dates or formative years but instead should reflect on the educational routes which have prepared them to read this book. The defining feature of Generation $T$ membership is an education about tourism, tourists and related topics, which is multidisciplinary, phenomenon centred and often ahistorical. If the educational route taken has been a combined pathway mixing subjects and courses in the social sciences as well as business and marketing and also includes various liberal options then an individual belongs to the Generation $\mathrm{T}$ (a short description for a tourism-focussed education). If readers have studied a single discipline as a major focus of undergraduate or first-degree education-effectively a three- to four-year concentration on one way of viewing the world-then the Generation T label does not apply. Generation T membership is growing and individuals in the cohort are successfully inhabiting the academic corridors of the world's universities and research centres which contribute to the analysis and teaching of tourism.

There are strengths and limitations in the preparation of Generation $\mathrm{T}$ members as researchers and educators. From a positive perspective, Generation $T$ can combine their ready access to the world's published material with the shifting dynamics of the tourism sector to establish a productive, contemporary and broad outlook. Nevertheless, an enduring difficulty can be a modest basis on which to interrogate new patterns of thought, most especially when these concepts and ideas derive from a long established discipline such as psychology, sociology, economics or anthropology.

The purpose of Chapter 1 in this volume is to provide an accessible overview of the disciplinary biography in psychology. It is hoped that by providing this background an effective and informed use of the positive psychology ideas which underpin this volume can be employed in many kinds of tourism studies. The focus is on the core psychology ideas used throughout the chapters in this book. For a reader already familiar with the intricate history of psychology, it will appear as an abbreviated account of a long journey. It may also be viewed as idiosyncratic as its purpose is 


\section{xvi Introduction}

to prepare for an understanding of the roots of positive psychology rather than to record all the historical pathways. To assist readers to check the approach taken to the research provided in Chapter 1, there are some publications and Internet resources which might be particularly helpful, particularly those of the American Psychological Association (http://www. apa.org/) and the British Psychological Society (http://www.bps.org.uk/). These sources are usefully supplemented by popular books written by wellcredentialed scholars such as the work of Furnham (2008) and Diener and Biswas-Diener (2008).

There are wider implications generated by the kind of review undertaken in Chapter 1 which repay some contemplation and reflection. These implications can be summarised with an alliterative trio of terms: productivity, politics and parasitism. The contrasting terms are quality, anarchy and symbiosis. The ideas constitute potential chapters in themselves, but in this context it can be simply observed that contemporary scholars are under political pressure to be productive and produce an array of publications for their careers and the status of their institutions. These pressures can result in the rapid borrowing of fashionable ideas, a form of parasitic plundering of the work of other areas. The responses to such pressures are understandable and much of the work produced in this way is still of high quality. Nevertheless, a close reading of the origin of the ideas and an effort to be anarchic in the sense of taking the time to independently assess the value and roots of the concepts offer the potential for exchange and symbiosis which reaches beyond some present achievements. Many of the historical figures in psychology discussed in Chapter 1 were colourful and independent figures finding their own way to lead the good life and flourish. If after completing this review the reader is stimulated to attack some of the original works, then there is the prospect of some surprisingly rich rewards and scholarly insights. 